\title{
An Empirical Analysis of the Relationship Between Enrolment in Finance Specialization and Employability: Effects of Graduates Skills
}

\author{
Beatrice Kinanu Anyuki ${ }^{1} \quad$ Dr. Grace Akinyi Musa ${ }^{2 *}$ \\ 1. PhD Student, Department of Accounting and Finance, University of Nairobi, Nairobi, Kenya \\ 2. Lecturer, Department of Accounting \& Finance, Technical University of Kenya, Nairobi, Kenya
}

\begin{abstract}
The purpose of the study was an empirical analysis of the relationship between students' enrolment in finance specialization and employability with effects of graduates' skills. Bachelor of commerce program takes a period of three to four academic years. The program has various specializations from which students are allowed to select their favorite areas at the start or end of the second academic year. One such area is finance specialization. Empirical research has shown that finance specialization is popular to most students. It was expected that students who graduated with finance specialization had been taken through the course contents by experienced and knowledgeable Instructors. They were also expected to have undergone both internal and external attachments that heightened their practical skills which would attract employers. However, empirical research shows that this has not been the case since most finance graduates in Kenya are not being absorbed into the job market. This phenomenon called for an empirical analysis between students' enrolment in finance specialization and employability with the effects of graduates' skills. The study adopted an ex-post facto research design with a linear regression model. The population of the study comprised of Kenyan universities management, Finance students and graduates and selected organizations. The data collection instrument was a questionnaire which had been distributed among the respondents. A pilot study was conducted which proved the reliability and validity of the research instrument. Findings revealed a significant relationship between enrolment in finance specialization and graduates' employability; a significant intervening effect of graduates' skills on the relationship between enrolment in finance specialization and employability. The study recommended the need to restructure the course content of finance to be more hands-on. Universities to limit the number of students specializing in finance based on high entry points to avoid over enrolment in finance specialization which comes with its limitations including massive unemployment; the government of Kenya to create more jobs to the youths and graduates if they are to realize Kenya vision 2030.
\end{abstract}

Keywords: Enrolment in Finance Specialization, Employability, Graduate Skills

DOI: $10.7176 /$ RJFA/11-12-13

Publication date:June 30th 2020

\section{Introduction}

1.1 Background Information

Unemployment has been a global issue as reported many countries across the world. Kenya's economy has been hardest hit by the unemployment issue as reported by various surveys. For instance, according to United Nations Development Programmes (UNDP), Kenya was ranked as having the highest unemployment rate in East Africa. In Kenya for instant, surveys have been carried out by various bodies concerning the unemployment rate. According to Kenya Economic survey (2019), 840,600 new jobs were created in that year when compared to 909,800 reported in (2017), an indication of a decrease in employment level. The unemployment state has been emphasised by the report from Kenya Social Protection and Job Programmes Public Expenditure Review which showed that the county's job creation had failed to keep pace with new job entrants.

According to report by the World Bank (2019), spending on job programmes in Kenya amounted to $0.3 \%$ of Government expenditure. This showed that spending had stagnated at 0.1 per cent of Gross Domestic Product (GDP) in recent years limiting the reach of job programmes. The rate was low compared to that of other countries like Brazil and Ghana that had dedicated at least 1.2 per cent of GDP to such programmes. A report from the Kenya National Bureau of Statistics survey (2019) stated that up to 19.5Million Kenyans were active in the labour force, majority of them in low-cadre jobs. This state of affairs indicated that there existed stiff competition on the quest for job opportunities in Kenya and the world at large.

In Economics, the law of demand and supply states that when prices are high, the supply will be high whereas demand will be low and when prices go down the supply will be low while demand will be high (Frakt \& Piper, 2014). It, therefore, follows that high enrolment in finance specialization has attracted a high supply of finance graduates when compared to the availability of job opportunities. This has consequently sky-rocketed the quality expected by the employers from finance graduates. The multiplier effect has been witnessed in the quest of employers for the most qualified finance graduates. This has consequently called for stiff competition on the 
quality of finance graduates on a survival for the fittest basis. There has been an urgent call for certain remedial actions to be undertaken by the universities and concerned educationalists. These have included; an analysis of proper finance course contents, engagement of qualified and experienced finance Instructors, enrolment of high entry-points of students into finance specialization, and exposure of finance students to the industry.

The study started by explaining graduates' skills and attributes that are valued by employers this was obtained from the scoping interviews with employer and Higher Education Interviews organizations. They found that there are characteristics, skills, and knowledge and intellectual capability elements that are required for specific roles. Besides, combinations of transferable skills were also deemed particularly relevant. These were: Team working; Problem-solving; Self-management; Knowledge of the business; Literacy and numeracy relevant to the post; ICT knowledge; Good interpersonal and communication skills; Ability to use own initiative but also to follow; instructions; Leadership skills where necessary; In addition to these skills, employers also highlighted the need for particular attitudes and outlooks including motivation, tenacity, and commitment. Overall, this is in line with the UKCES (2009a)

It was expected that proper delivery of finance course contents would act as students 'eye-openers' into a finance career. Therefore, universities were expected to engage qualified and experienced finance Instructors to deliver using appropriate teaching methodologies (Kofi, 2014; Odum, 2015 \& Jayaprakash, 2005). It was thought that this would likely help in producing high caliber finance graduates ready for the job market (Shattock, 2007). Also, enrolment of students into finance specialization with high-grade points was necessary given the quantitative nature of the course. It was expected that this would accelerate the performance of finance students at the universities which would later be transferred to the job market and the business world at large. Exposure of finance students to both internal and external attachments was expected to sharpen students' industrial knowledge which would later make the finance graduates relevant in the industry (Lisa, Hennelova, \& Newman, 2019).

These facts notwithstanding, research has shown that there has been mass production of finance graduates, most of who have not been absorbed in the job market (Kalufya \& Mwakajinga, 2016). According to a survey carried out by the Kenya Bureau of Statistics (2019), a total of 7 Million Kenyans were unemployed, out of this 1.4 Million had been desperately looking for jobs. The rest had given up on job hunting with the rest going back for further studies. Unfortunately, once these students are through with the post graduate degrees, most of them get part time employment at the universities, some are taken in as internship where they are not paid for services rendered (Cyrus Nyakundi, 2019; Musa, 2020; Shattock; 2007 \& Swanson, 2010) It was noted that unemployed Kenyan finance Graduates' formed a larger fraction of the unemployed 7 million group. This implied that competition for finance graduates was stiff, this called for the production of high caliber finance graduates. This could only be achieved if the universities worked together with Kenyan Commission of Education (KCUE) undertook a complete restructure of finance course contents that was more practical (Shattock, 2007). For instance, the deliveries on analysis and interpretations of the financial statements to students required seeking the services of experts from the industries. It was expected that this could have heightened the finance students' comprehensibility of the practical aspects of analyzing and interpreting financial statements of different organizations amicably.

Empirical studies showed that most advanced finance courses were not comprehended by finance students. This was due to the fact that most full time Instructors were not well conversant with the topics or most of them were fresh graduates from universities and lacked teaching experience Rajapakse (2017). As a result, they relied mostly on the services of part time Instructors, whose population outweighed those of full time Instructors (Musa,2020). This was partly due to their inability to handle advanced courses. Reasons included a lack of experience or knowledge of the subject matter. The Part-time Instructors at the universities, however, faced a lot of challenges which made them not deliver well. For instance, most of the part-time Instructors were not financially rewarded for work done. Their lives at the universities were pathetic; they were not given desks to prepare their work and were looked down upon by full time Instructors. These made them very mobile in pursuit for greener pastures elsewhere. Most of them ended up leaving with students scripts in the hope of being paid their dues which were in areas. Given these challenges, no proper output could have been expected from discontented part time Instructors (Cyrus Nyakundi, 2019; Musa, 2020). The result saw the production of poor skilled finance graduates who could not match the stiff competition in the business world (Demagalhaes \& Lisa, 2011).

Past studies reported that enrolment into finance specialization required high caliber students due to the quantitative and practical nature of the course. This required full comprehension and mastery of the basic concepts of the course at the earliest opportunity possible for easier application at later stages of finance courses and career (Pandey,2016) However, it has been observed that the entry points of students into finance specialization have been very low when compared to the nature of the course. In majority of cases, these students had attained a bare minimum in the pre-requisite subjects such as mathematics and English. Also, some of the students did not study business studies in high schools which were a foundational course in finance. Most students ended up scoring low marks in finance since they found the course to be difficult, hence could not measure to the job market requirements (Lisa, Hennelova, \& Newman,2019; Amen, 2014) 
In order for finance graduates to fit into the stiff employment competition in Kenya's economy, it was necessary that students engaged in internal and external Industrial Based Learning. This would go a long way in sharpening their practical skills to match the expectations and requirements of the job market (Lam and Tang (2019). Internal attachments required that finance experts were invited from the industry to take students through industry requirements. External attachment, on the other hand, required students to be attached in the relevant fields; Finance students were to be attached in finance departments of various organizations (World Bank, 2019). This would enable them get 'first-hand 'experience with supervision from the industry and universities. All these were expected to give fiancé students a competitive edge against their competitors in anticipation for job opportunities (Rajapaske, 2017).

Numerous studies have been conducted on graduates' employability including; A Sri Lankan study by Rajapakse (2017), assessed the importance of soft skills on the employability of finance graduates. Findings revealed the priority in rankings of different abilities as 'very high.' 'High' and 'very low' based on skills assessed. A Tanzanian study by Kalufya and Mwakajinga (2016), assessed the employability of graduates from Higher Education Institutions. Findings showed that there was a significant difference in prioritization of the employability skills between employers and final year students.

An Australian study by (Teale, 2013), assessed the improving of financial planning graduates employability through enterprise education. Findings revealed that the university and the profession were more closely integrated with the financial planning students. This enabled the graduates to be fully competent and they finally became employees of employers' choice.

A study by Shattock (2007), assessed university education given to students and established that it produced half- baked graduates whose skills did not match employers' requirements. These studies were conducted mainly in developed countries without universal agreements. An empirical analysis of enrolment in finance specialization and employability with the effects of graduate skills in Kenya's economy was lacking.

\subsection{Statement of the Problem}

According to the United Nations Development Programmes (UNDP), Kenya was ranked as having the highest unemployment rate in East Africa. This fact was evidenced by a survey from the Kenya Bureau of Statistics (2019) which reported that a total of 7 Million Kenyans were unemployed, out of this 1.4 Million had been desperately looking for jobs. The rest had given up on job hunting with the rest going back for further studies. It is important to note that unemployed finance Graduates' formed a larger fraction of this group given that they were the majority of Kenyan graduates. This meant that there was stiff competition among graduates in pursuit of job opportunities. The big question the study sought to address was whether Kenyan finance graduates were ready for the competition in terms of characteristics skills, knowledge of the subject matter and intellectual capabilities. Prior studies showed that most finance students were; taught by the inexperienced Instructors who lacked teaching experience (Kofi, 2014; Odum,2016) were not qualified in finance or were handled by mobile part-time Instructors who did not receive financial rewards for services rendered (Cyrus Nyakundi, 2019; Riechi, 2012 \& 2020).

Further, it was established that entry points into finance specialization did not match the requirements of the course as most finance students were apprehensive towards quantitative subjects. Most finance students were not exposed to either internal or external industrial based learning, they thus lacked the practical skills required by employers (Rajapakse, 2017). This implied that any creation of job opportunities would still lock them out since they were 'not work-ready' (Shattock, 2007; World Bank \& IMF, 2019; Lam \& Tang, 2019 \& Amen, 2014). Numerous studies which have been conducted saw the creation of contextual, conceptual, theoretical, and methodological gaps. These included;

A Sri Lankan study by Rajapakse (2017) assessed the importance of soft skills on the employability of finance graduates. Findings revealed priority in rankings of different abilities ranging from 'Very high.' 'High' and 'Very low.' The study was conducted in Sri Lanka, could the results be replicated in a Kenyan context? A Tanzanian study by Kalufya and Mwakajinga (2017) assessed the employability of graduates from Higher Education Institutions. The study adopted a descriptive research design and the results were analyzed quantitatively. Findings showed that there was a significant difference in prioritization of the employability skills between employers and final year students, this created contextual and methodological gaps for the current study.

An Australian study by Teale (2013) assessed improving financial planning graduate employability through enterprise education. The study employed the use of Goetz (2005) methodological model. Findings revealed that the university and the profession must be more closely integrated for financial planning students to graduate as fully competent and in so doing become an employee of choice. This was contrary to the logistic regression model applied by the current study. A study by Shattock (2007) assessed the quality of university education given to students and established that the system was poor as it lacked various essential inputs needed in the job market such as practical skills. They ended up producing ' half- baked ' graduates whose skills did not match employers' requirements. These studies were conducted mainly in developed countries without universal agreements. The big question the current study sought to answer was whether there existed any relationship between enrolment in 
finance specialization and employability with the effects of graduate skills in Kenya's economy.

\subsection{Objectives}

The main objective of the study was an empirical analysis of the relationship between enrolment in finance specialization and employability, with effects of graduates' skills.

The following two specific objectives were developed;

(i) To evaluate the relationship between enrolment in finance specialization and employability of graduates

(ii) To determine the intervening effect of graduates skills on the relationship between enrolment in finance specialization and employability of graduates.

\subsection{Hypotheses}

The following two null hypotheses were developed;

Ho1: There was no significant relationship between enrolment in finance specialization and employability of graduates.

Ho2: There was no significant intervening effect of graduates' skills on the relationship between enrolment in finance specialization and employability of graduates.

\section{Literature Review}

The study reviewed both theoretical and empirical literatures. Theoretical literature was based on Conflict theory. Empirical literature compared past studies against current study and thereby highlighted gaps. The current study used the following variables; course consents of finance, entry points into finance specialization, skills posed by graduates and employability of graduates.

\subsection{Conflict Theory}

The Conflict theory was developed by Karl Marx (1818-1883). The theory purports that due to the never-ending competition for limited resources society will always be in a state of conflict. According to Karl Marx, society was divided into classes the bourgeoisie (rich) and the proletariat (poor), who were in constant struggle. This theory implies that those in possession of wealth and resources will protect and hoard those resources, while those without will do whatever they can to obtain them.

The theory was relevant to the study in that the numbers of finance graduates who are in search of employment are too many yet the jobs available are few (limited resources). The current study applied the theory of conflict based on a number of its assumptions; that there are two classes of people, the employers and the finance graduates. The employers have an advantage over the graduates in that they control the number of graduates who are employed based on the available opportunities. This theory also highlights the conflict between employers and universities which stems from employers being unsatisfied with university efforts to provide graduates with adequate generic skills to perform in the working environment (Selvadurai, Choy, \& Maros, 2012). It also assumes that there are limited resources. This means that the jobs available to be taken up by these finance graduates are few yet the numbers of finance graduates fresh from the university are large. This results in the exploitation of these graduates, for example may be engaged as interns and not paid or paid meager salaries and in most cases they may be unemployed.

The conflict theory has been critiqued by several researchers on the ground that it is based on access to power and opportunities. These researchers counter it with the consensus theory. The consensus theory is based on the belief that human capital injection in higher learning institutions will ensure the employability of graduates. It tends to blame those in academia for not instilling the proper skills through curriculum and appropriate pedagogical methods to students (Selvadurai, Choy, \& Maros, 2012). However, these did not compromised the quality of conflict theory which informed the study variables given; course contents of undergraduate finance, entry points into finance specialization, skills required from finance graduates, and employability of finance graduates.

Despite the criticisms, the conflict theory has been used in some studies including that of Brown, Hesketh, and Williams (2003) concluded that from a conflict view much of the talk about the development of employability skills, especially personal and social skills, are reflections of a mismatch between credentials and the realities of knowledge capitalism. As more and more contestants enter the job market with graduate qualifications the value of credentials as a screening device declines. Therefore, personal qualities are emphasized in an attempt to legitimate the reproduction of inequalities, rather than improve productivity.

\subsection{Empirical Review}

The study reviewed literature based on the variables used including; Course Contents of finance (Instructors, teaching methodologies, entry points into finance Specialization, Industrial Based Learning); Skills required by finance Graduates on Employability. Numerous studies have been conducted on graduates' employability in most countries across the world. The studies recognized that unemployment of graduates had been a global issue worth 
attention.

\subsubsection{Course Contents of Finance and Finance Graduates Employability}

The study's first objective was an evaluation of the relationship between course contents of finance and employability of finance graduates. The study considered Instructors, teaching methodologies, entry points into finance Specialization, Industrial Based Learning as sub- sets of finance course contents. Prior studies showed that qualified and experienced Instructors were expected to use appropriate teaching methodologies (Musa, Amadi, Odoyo \& Sagwa, 2018). This ensured that students had good comprehension of the subject matter of the relevant disciplines. This improved their performance in the course and later in the business world (Swanson, 2010). Achievement of this dream was accelerated by the enrolment of high entry points into various specializations especially those areas which are quantitative based. Prior studies have reported that high entry points into competitive courses would eliminate the oversupply of graduates. The few qualified graduates would then compete with the limited job opportunities. According to the Higher Education Initiatives (Fulgence, 2015), it was recommended that engagement of students in Industrial Based Learning (IBL), sharpened their skills which made them acquire practical skills required by employers in the job market.

An Australian study carried out by (Teale, 2013) assessed improving financial planning graduate employability through enterprise education. The study concentrated on Financial planning which required students to display tacit learning. This study used an adaptation of the Goetz (2005) model to demonstrate how curricula can provide a smoother progression into the financial planning profession. Further, some teaching strategies were described to provide a closer connection with the profession. Findings revealed that the university and the finance profession must be more closely integrated for financial planning students to graduate as fully competent and in so doing become an employee of choice. This was contrary to the current study whose focus was on finance specialization among the bachelors of commerce students and how Commission of University Education (CUE), Kenya Universities and Colleges Central Placement Services (KUCCPS) and the professional experts from industries could work as a synergy to ensure that universities produce high caliber finance graduates to compete in an environment where the supply of graduates outweigh availability of job opportunities.

A Tanzanian study by Kalufya and Mwakajinga (2017) assessed the employability of graduates from Higher Education Institutions. The study adopted a descriptive research design and the results were analyzed quantitatively. Findings showed that there was a significant difference in prioritization of the employability skills between employers and final year students. The study concentrated on the employability of all graduates from institutions of higher with different rankings of skills required by the employers. However, the current study concentrated on finance graduates only and factors which would accelerate their employability in a job scarcity environment. Further, prior study was conducted in a different country from that of the current study; can the findings of the prior study be replicated on Kenyan finance graduates?

In South-Eastern Europe, Atanasovski, Trpeska, and Lazarevska (2018), surveyed students enrolled in an accounting degree program. The aim of the study was an assessment of employers' perceived importance given a wide range of generic and technical skills for successful entrance to the profession. The specific objective was an investigation into the perceived effectiveness of the university accounting education to develop important skills at an appropriate level. The results indicated agreement between the two respondent groups that the education process and program needed improvements to allow for better development of technical and generic skills among successful graduates. The focus of the current study was on finance graduates, however, the concentration of developing students' skills appropriately seemed to be similar to the current study. Can the findings of the prior study be replicated to finance graduates in a Kenyan context?

2.2.2 Skills Required by Finance Graduates on Employability

According to Higher Education Initiatives, graduates' skills and attributes that are valued by employers were found to include: characteristics skills, knowledge and intellectual capability elements that are required for specific roles. Besides, combinations of transferable skills were also deemed particularly relevant. These were: Team working; Problem-solving; Self-management; Knowledge of the business; Literacy and numeracy relevant to the post; ICT knowledge; Good interpersonal and communication skills; Ability to use own initiative but also to follow; instructions; Leadership skills where necessary; In addition to these skills, employers also highlighted the need for particular attitudes and outlooks including motivation, tenacity, and commitment. Overall, this is in line with the UKCES (2009a).

A study conducted in Bahir Dar, Ethiopia by (Woya, 2019) assessed the employability and competency of statistics graduates. Data was collected using a structured questionnaire. The study analysis model adopted was a Kaplan-Meier estimate to compare the duration of unemployed times from two or more groups. The study revealed that there was a percentage of graduates who were not yet employed and never been employed. The study recommended that the department needed to link up with the different government organizations and NGOs to improve the employability of statistics graduates. However, the current study focus was on finance teaching of students specializing at the universities and the best way skills acquisitions could be achieved to make them relevant in the job market and thus survive in a competitive environment of mass unemployment. 
A study by (Rajapaske, 2017) assessed the importance of soft skills on the employability of finance graduates. Findings revealed the priority in rankings of different abilities following; quality of work, ability to meet deadlines, positive attitudes towards work, and self-confidence as "very high" in importance. Motivation to learn, ability to manage stress, motivation to develop skills, ability to work independently, maturity in making decisions, team playing spirit, computer literacy a, IT literacy, creativity, innovativeness, general behavior, grooming, and readiness were ranked as "high". Good academic records were ranked "very high" and professional qualifications were ranked "high". Extracurricular activities were ranked "moderate "and gender, marital status, and family background was ranked "very low ". The focus of this study was specifically on the importance of soft skills on the employability of finance graduates. The concentration of the current study was specifically on mastery of course contents of undergraduate finance and the production of relevant graduates to take up finance jobs in the business world in a competitive economy.

It is clear from the empirical studies assessed that most graduates across the world lacked skills which employers required at the workplace. These made them considered as half-baked and not work - ready by their prospective employers. Despite, studies on lack of graduates skills and mass unemployment experienced by most economies across the world, little literature exists with regards to finance graduates in Kenya's economy, justifying; An empirical assessment of the relationship between finance graduates and employability with the effects of graduates' skills in Kenya's economy was lacking.

\subsection{Conceptual Framework}

The conceptual framework depicted the relationships between the independent variable; Finance Specialization; intervening variable, Graduates Skills and dependent variable; Employability of finance graduates. An intervening variable is an integral part of a cause-effect relationship; it makes it easier to understand how the independent variable affects the dependent variable and what governs the relationship.

\begin{tabular}{|c|c|c|c|}
\hline Fin $\mathrm{Cn}$ Cirlintion & \multicolumn{2}{|l|}{$\mathbf{H}_{01}$} & \multirow{2}{*}{$\begin{array}{l}\text { Employability } \\
\text { Finance Graduates, }\end{array}$} \\
\hline - Course content & Graduates Skills & $\mathbf{H}_{02}$ & \\
\hline $\begin{array}{l}\text { - } \quad \text { Entry points } \\
\text { - Industrial Based } \\
\text { Learning }\end{array}$ & $\begin{array}{ll}\text { - } & \text { Subject Knowledge } \\
\text { - Intellectual } \\
\text { capabilities }\end{array}$ & & $\begin{array}{l}\text { - } \quad \text { Competent } \\
\text { - } \quad \text { Not } \\
\text { competent }\end{array}$ \\
\hline
\end{tabular}

Figure 1: Conceptual Framework

Source: Authors (2020)

Ho1 $_{0}$ Depicts a relationship between finance specialization and finance graduates' employability.

Ho2: Depicts an intervening effect of graduates' skills on the relationship between finance specialization and graduates' employability.

From the conceptual framework above, it is clear that when finance students have enrolled into finance specialization with the required grades, taught using finance course contents, undergone IBL, the student are expected to be absorbed into the job market. However, full competency can be accelerated based on the intervening variable which calls for possession of characteristic skills, knowledge of finance contents and intellectual capabilities. Lack of graduate skills would likely result into non-competency. This implies that competencies incorporate a set of skills with capabilities and knowledge.

\section{Methodology}

The study adopted an ex-post-facto research design. It sought to empirically assess the relationship of finance specialization on the employability of finance graduates with effects of graduate skills. The design was considered appropriate since it can be used to test hypotheses about cause and effect or co-relational relationships. In an expost facto design, attempts are made to determine the influence of a variable on another variable and test a state using statistical hypothesis testing techniques (Tunji, 2012).

The study relied heavily on primary data obtained from structured questionnaires to managers of different organizations, University managements, and finance graduates. Simple random sampling was used to identify the number of respondents as 200 .

\section{Data Analysis}

Data obtained from the questionnaires was analysed and the following was established:

The study had an $88 \%$ response rate since 176 questionnaires were answered appropriately. 
Table 1: Regression model of Finance Specialization and Graduates Employability

\begin{tabular}{cccccc}
\hline \multicolumn{7}{c}{ Model Summary } \\
\hline $\mathrm{R}$ & $\mathrm{R}^{2}$ & Adjusted $\mathrm{R}^{2}$ & Std. Error & F Change & Sig. \\
\hline .559 & .313 & .308 & 5.438 & 79.25 & .001 \\
\hline \multicolumn{5}{c}{ Regression Coefficients } \\
\hline Beta & Std. Error & t-statistics & Sig. \\
Finance Specialization & 6.974 & .517 & 13.501 & .000 \\
\hline
\end{tabular}

Table 1 shows a positive relationship between Finance Specialization and graduates employability $(R=$ 0.559). Also, the value 0.313 indicates that Finance Specialization only explains $31.3 \%$ of the total variations in graduates' employability. Consequently, Finance Specialization explains only $30.8 \%$ of changes in finance graduates' employability as represented by the adjusted $\mathrm{R}^{2}$. It can therefore be concluded that there are other factors not studied in this study that contribute $69.2 \%$ of the changes in finance graduates' employability. The model is however significant since the p-value 0.001 is less than 0.05 .

From the regression coefficients, the constant regression coefficient and that of the independent variable were $6.974(S E=0.517)$ and $2.039(S E=0.229)$ respectively. These regression coefficients were both significant at $5 \%$ level since the p-values were less than 0.05 .

The coefficient value for the independent variable implied that for every improvement in the pre-specified aspects of Finance Specialization by one unit, would result to improvement in graduates' employability by 2.039 units. Thus, based on the significance of the regression coefficient, we express the equation for the regression model as follows:

$$
Y=2.039 X+6.974
$$

The study rejected the null hypothesis $\left(\mathbf{H}_{01}\right)$ at $5 \%$ level of significance about the non-significance of the effect of finance specialization on graduates' employability in Kenya.

Table 2: The intervening effect of Graduate skills on the relationship between Finance Specialization and Graduates Employability

\begin{tabular}{|c|c|c|c|c|c|}
\hline \multicolumn{6}{|c|}{ Model Summary } \\
\hline $\mathrm{R}$ & $\mathrm{R}^{2}$ & Adjusted $\mathrm{R}^{2}$ & Std. Error & F Change & Sig. \\
\hline .721 & .521 & .515 & 4.558 & 93.96 & .002 \\
\hline \multicolumn{6}{|c|}{ Regression Coefficients } \\
\hline & & Beta & Std. Error & t-statistics & Sig. \\
\hline (Const & & 5.344 & .472 & 11.325 & .000 \\
\hline Finance & ization & 0.880 & .233 & 3.764 & .001 \\
\hline Gradua & & 1.060 & .122 & 8.659 & .000 \\
\hline
\end{tabular}

Table 2 shows a positive relationship of the intervening effect of Graduates' skills $(R=0.721)$. Also, the value 0.521 indicates that Finance Specialization and Graduates skills explain $52.1 \%$ of the total variations in graduates' employability. Consequently, Finance Specialization and Graduates skills explain only 51.5\% of changes in finance graduates' employability as represented by the adjusted $\mathrm{R}^{2}$. It can therefore be concluded that there are other factors not studied in this study that contribute $48.5 \%$ of the changes in finance graduates' employability. The model is however significant since the p-value 0.001 is less than 0.05 . It is important to note that the inclusion of the intervening variable, Graduates skills, improves the regression model.

From the regression coefficients, the constant regression coefficient and that of the independent variable and intervening variable were $5.344(S E=0.472), 0.880(S E=0.233)$ and $1.060(S E=0.122)$ respectively. These regression coefficients were both significant at $5 \%$ level since the p-values were less than 0.05 .

The coefficient value for the independent variable implied that for every improvement in the pre-specified aspects of Finance Specialization by one unit, would result to improvement in graduates' employability by 0.880 units. For every improvement in the intervening variable, Graduates' skills by one unit would result to improvement of graduates' employability by 1.060 units. Thus, based on the significance of the regression coefficient, we express the equation for the regression model as follows:

$$
Y=5.344+0.880 X_{1}+1.060 X_{2}
$$

The study rejected the null hypothesis $\left(\mathbf{H}_{02}\right)$ at $5 \%$ level of significance about the non-significance of the intervening effect of graduate skills on the relationship between finance specialization and finance graduates' employability in Kenya.

\subsection{Findings}

The first objective of the study was to evaluate the relationship between enrolment in finance specialization and the employability of graduates. The study also hypothesized that there was no significant relationship between 
enrolment in finance specialization and the employability of graduates.

The study established that there was a significant relationship between enrolment in finance specialization and the employability of graduates. The study defined finance specialization in terms of course content and entry points into finance specialization.

Similar sentiments were shared by a study conducted by Shattock (2007), which established that there was a problem with the course content used to teach students in the Universities as most of them were 'green' in the business world (Teale, 2013). Findings revealed that the university and the finance profession must be more closely integrated for financial planning students to graduate as fully competent and in so doing become an employee of choice. Atanasovski, Trpeska, and Lazarevska (2018), study indicated agreement between the two respondent groups that the education process and program needed improvements to allow for better development of technical and generic skills among successful graduates.

The second objective of the study was to determine the intervening effect of graduates' skills on the relationship between enrolment in finance specialization and employability of graduates. The study had hypothesized that there was no significant intervening effect of graduates' skills on the relationship between enrolment in finance specialization and employability of graduates. Findings revealed a significant the intervening effect of graduates' skills on the relationship between enrolment in finance specialization and employability of graduates.

This finding was consistent with a study conducted by Borges (2014) and Kavangah and Drennan (2008) established a mismatch between the skills posed by graduates on entry into the job market and employers expectations. A report from the World Bank and International Monetary Fund (2019) furthered this by stating that most employers across the world have ended up employing persons with lower qualifications to undertake graduates' work. Similar sentiments were shared by a study that established that the entry points into various specializations in Universities were lower such that the results were half-baked in the business world Kavangah and Drennan (2008). A by Kalufya and Mwakajinga (2017) Findings showed that there was a significant difference in prioritization of the employability skills between employers and final year students.

Empirical studies established a mismatch in skills posed by graduates and employers requirements in various areas of specializations, the current study; however, focused mainly on how to finance students could be trained to survive in the competitive business world.

\subsection{Significance of the Study}

University Management: There is need to; Work with Commission of University Education to Restructure the course content of finance to be more hands on rather than theoretical; Recruit more qualified and experienced accounting Instructors to apply relevant teaching methods to appropriate topics in accounting courses and more emphasis put especially on preamble accounting courses; Engage professional accounting experts from industry (ICPAK); Introduce more internal and industrial attachments for students to be more practical in the accounting job. This will go a long way in producing quality accounting graduates who are more 'hands on 'and relevant in performing duties as per the requirements of the employers.

Professional Bodies (KASNEB \& ICPAK): Will see the need to offer Industrial Based Attachment training chances for accounting students in their organizations. This will introduce accounting students to the practical accounting skills expected of them early enough. Thus avoiding mismatch between skills posed by fresh accounting graduates on entry into the job market and employers expectations and requirements.

Government of Kenya: Through Kenya Universities and College Central Placement Service (KUCCPS) and Commission of University Education will have to revisit the university entry cluster points for bachelors of commerce and finance courses. This is due to the fact that finance career requires high calibre students with integrity to enable them prepare and interpret financial statements of various organizations amicably.

Employers: Will have to offer attachments and internships programmes which will provide finance students with the relevant skills needed in the job market, hence eliminating the mismatch which has been existing between skills posed by finance graduates and employers' expectations and requirements.

\subsection{Limitations, Justifications and Suggestions for Future Researchers}

Contextual Limitation: The current study concentrated on finance specialization and employability of finance graduates. This was contrary to other studies that assessed Kenya's unemployment of the youths. However, this did not compromise the quality of research as the high number of enrolment in finance option is a worrying trend in all Kenya's Universities that offer Bachelors of Commerce programme. Future studies should consider the areas not covered by the current study.

Conceptual Limitation: The current study concentrated on course contents of finance specialization, entry points into finance specialization and employability of finance graduates. Other variables could have been applied in the same study such as Enrolment to finance specialization in finance units. However, this did not compromise the quality of the study as the variables helped in achieving the set objectives and hypothesis developed. Future 
researchers should consider new variables not considered by the current study.

Theoretical Limitations: The current study applied the theory of consumer behaviour. It could have applied other career choice theories. However, this did not compromise quality of the research. The theories used informed the study variables. Future studies should consider using other career choice theories the left out by the current study.

Methodological Limitation: The study adopted cross sectional research design and purposive random sampling method. It was not possible to travel outside of Nairobi as a result of lock downs due to covid- 19 pandemic. However, this did not compromise the quality of research. Future studies should consider other methods such as census and longitudinal research design once business gets back to usual.

\section{Contribution to the Body of Knowledge}

The greatest contribution the study has brought in the body of knowledge is the call for a strong partnership and involvements with all parties concerned including; Kenyan Universities, Kenya Universities and colleges Central Placement Services (KUCCPS), Commission of Universities Education (CUE), Government of Kenya and Employers from different organizations. The formed body will ensure restructure of relevant course contents of finance; recruitment of qualified and experienced finance Instructors who have full mastery of course contents using appropriate teaching methodologies. Further employers will ensure that students are attached in relevant organizations where they will get fast hand industry experience, hence production of quality finance graduates who are work-ready. The government of Kenya will ensure creation of more jobs to the youths and graduates if they are to realize Kenya vision 2030.

\section{Conclusion}

Course Content of Finance Specialization: This should be made hands-on by introducing more internal and external attachments. Professionals from the industries should be given some practical areas to handle. This will create self-employment among the graduates. For example, they should be taught how to analyse practical financial statements of different organizations. This will introduce them to consultancy work once out of Universities which is a form of self-employment.

Enrolment into finance specialization: Universities should change entry points of students specializing in finance. Since finance is a set of all other Bachelors of Commerce, it should only attract brilliant students to avoid mismatch in skills of finance graduates against employers' expectations and requirements. To discourage mass enrolment, Universities should introduce examinations that only successful students should be allowed into the specialization. This will discourage average students and automatically reduce the numbers.

Professional Career Guidance to Bachelors of Commerce Students: Bachelor of Commerce students should be guided professionally into venturing in other specializations such as accounting which has been reported to have low uptake (Musa \& Sagwa, 2020; Geiger \& Oligby, 2000). This will enable them not scramble for interviews when called upon and hence employment.

Employability of Finance Graduates: One of the pillars of Kenya's vision 2030 was the development of finance sector of the economy. Realization of this would create more job opportunities not only to finance graduates, but the entire Kenyan employable citizens. It is also clear that with massive unemployment, Kenya as a country will lag behind not only in East Africa, but the entire world at large.

\section{Acknowledgement}

Our heartfelt thanks go to Madam Lucy Ajwang Otieno for accepting to collect data for this paper. Madam Lucy also contributed towards this journal by bring in the financial knowledge to the paper without which it could not have been possible to incorporate the finance expertise. We also most sincerely thank our analyst, Sandra Beldine Otieno very much for ensuring that a perfect methodology and data analysis was manifested in this manuscript. Our endless thanks go to our families headed by our husbands, Mr. Lawrence Karuti Muriuki and Engineer Amos Akelo for creating conducive atmospheres that enabled us conduct this study. Our utmost thanks go to Mr. Muriuki, a Lecturer in the department of Governance and Legal Studies of the Technical University of Kenya, for ensuring that the paper followed a systematic logical flow of English grammar. Our sincere thanks go to Professor Alexander, the chief editor of IISTE together with the review team for the enormous work done by pointing out the areas to be corrected which made the final manuscript perfect. We also thank IISTE fraternity for their continual quick responses towards reviewing the manuscripts of their authors in record time. Last but not least, I thank The Almighty God our Father for granting us good protection and health to ensure that this research was accomplished even during this covid-19 pandemic period. To God be the glory, Amen.

\section{References}

Amen, U. (2014). Employers expectations versus performance of fresh graduates: Business schools. Market Forces journal of management, business and economics, 39-50. 
Atanasovski, A., Trpeska, M., \& Lazarevska, Z. B. (2018). Accounting Students' and Employers Perceptions on Employability Skills in the SEE Country. European Financial and Accounting Journal, 55-72.

Borges, L. F., Santos, C. K., \& Leal, E. A. (2014). Quality in Educational Service: Expectations Versus Performance in the Accounting Undergraduate Course. European Scientific Journal, 10 (1), 100-114.

Brown, P., Hesketh, A., \& Williams, S. (2003). Employability in a Knowledge Driven Economy. Journal of Education and Work.

Demagalhaes, R. W., \& Lisa, R. (2011). Factors Affecting Accounting Students' Employment Choices: A Comparison of Students' and Practitioners' Views. Britain: Publishers.

Dibabe, T. S., Wubie, A., \& Wondmagegn, G. (2015). Factors that Affect Students Career Choice in Accounting: A Case of Bahir Dar University. Students Research Journal of Finance and Accounting, 6(5), 146.

Frakt, A., \& Piper, M. (2014). Microeconomics made simple:Basic Principles. Simple Subjects LLC.

Fulgence, K. (2015). Employability of Higher Education Institutions graduates:Exploring the influence of Entrepreneurship Education and Employability Skills Development Program Activities in Tanzania. School of Economic Disciplines Germany.

Geiger, M. A., \& Ogilby, S. M. (2000). The first course in accounting: student's perceptions and their effect on the decision in accounting. Paulines Publications Africa.

Jayaprakash, J. (2005). Strategies in teaching Accounts in Higher Education.

Kalufya, N., \& Mwakajinga, L. (2016). Employability of Graduates from Higher Education Institutions in Tanzania. Institute of Social Work Journal, 51-68.

Kavangah, M., \&Drennan, L. (2008). What Skills and Attributes Does an Accounting Graduate Need? Evidence from Students' Perceptions and Employer Expectations. Accounting Finance (Vol. 48).

Kenya Vision. (2030). Government of Kenya.

Kofi, E. M. (2014). Using Group Method of Teaching to Address the Problem of Large Class Size. An Action Research Journal of Learning and Development, 4 (2), 124-134.

Lam, B., \& Tang, H. (2019, September 14). Employability: a mismatch of expectation and skills. Hong Kong.

Lisa, E., Hennelova, K., \& Newman, D. (2019). Comparison between employers' and students' expectations in respect of employability skills of university graduates. International Journal of Work-Integrated Learning, 7182.

Musa, G. (2020). An Assessment of the Relationship Between Part-time Instructors and Performance of University Graduates in Kenya's Economy: Effects of Salary Payments. European Journal of Business and Management Research, 5(2).

Musa, G. A., \& Sagwa, E. V. (2020). Joint Effect of the First Course in Accounting, Students' Performance and Career Guidance on Choice of Accounting Specialization. The International Journal of Business and Management, 8(3).

Musa, G., Amadi, A., Sagwa, E., \& Odoyo, S. (2018). Influence of Introductory Accounting Course Teaching Methodology on Students' Choice of Accounting Major in Kenyan Universities. Research Journal Of Finance and Accounting, 9(7), 168-174.

Odums - Naboth, A. (2014). Critical Assessment of Just-In-Time Teaching Method as Against Conventional Teaching Method on Academic Performance of Business Studies. Students Journal of Educational and Social Research, 4 (5), 25-30.

Rajapaske, R. P. (2017). Importance of Soft Skills on Employability of Finance Graduates. ISSN:2321-8819, 136141.

Riechi, A. (2012). Revenue diversification in Kenya's public universities and implications for efficiency and equity: an analysis of educational finance in the African context. Phd Thesis.

Selvadurai, S., Choy, E. A., \& Maros, M. (2012). Generic Skills of Prospective Graduates from the Employers' Perspectives. Asian Social Science, 295-303.

Shattock, M. (2007). Higher Education Management and Policy. Journal of the Programme, 19 (2).

Swanson. (2010). Assessment of the Accounting cycle. Retrieved from http://digitalcommons.wku.edu/stu

Teale, J. (2013). Improving Financial Planning Graduate Employability Through Enterprise Education. Australasian Accounting,Business and Finance Journal, 91-106.

Tunji, S. T. (2012). Accounting Information as an aid to management decision making. International Journal of Management and Social Sciences Research.

Woya, A. (2019). Employability among Statistics Graduates: Graduates' Attributes, Competence and Quality of Education. Education Research International. 